\title{
Progress in Research and Development on Yams (Dioscorea spp.) in Maluku Islands, Indonesia: Achievements and Challenges
}

\author{
Semuel Leunufna* \\ Faculty of Agriculture, Pattimura University Ambon, Maluku, Indonesia \\ *Corresponding author: Semuel Leunufna, Faculty of Agriculture, Pattimura University Ambon, Center for the \\ Conservasion of Maluku's Biodiversity, Jl Ir M Putuhena. Kampus Poka, Ambon, 97233, Maluku, Indonesia
}

\section{ARTICLE INFO}

Received: 幽 July 20, 2020

Published: 幽 July 29, 2020

Citation: Semuel Leunufna. Progress in Research and Development on Yams (Dioscorea spp.) in Maluku Islands, Indonesia: Achievements and Challenges. Biomed J Sci \& Tech Res 29(2)-2020. BJSTR. MS.ID.004764.

Keywords: Dioscorea spp; Diversification; Research; Development; Maluku Islands; Genetic Erosion

Abbreviations: USAID: United States Agency for International Development; IPK: Institut fuer Pflanzengenetik und Kulturpflanzenforchung; DAAD: Deutcher Austauchdienst

\section{ABSTRACT}

Tuber crops, including yams (Dioscorea spp.) have been playing an important role in the menu of the community of Maluku islands. To optimize contribution of yams (Dioscorea spp.), a number of studies have been conducted at the Faculty of Agriculture, Pattimura University. The findings indicated that more than 100 cultivars belonging to five different species of Dioscorea namely D. alata L., D. esculenta (Lour.) Burkill., D. pentaphylla L., D. hispida Dennst and D. bulbifera L. distributed thoughout Maluku islands, in which, D. alata and D. esculenta are predominant and Central Maluku has the highest number of cultivars. In terms of field experiments, increasing seed size (cut tuber) from 40-50grams up to 190-200grams, increase the production of $D$. esculenta. Seed placement with the tuber skin faced-down provide higher yield for $D$. esculanta in comparison to that when the tuber skin faced-up. Soil fertilization with potassium fertilizer $\left(\mathrm{K}_{2} \mathrm{O}_{5}\right)$ of $80 \mathrm{~kg} /$ ha give the highest production $(7.72$ tons $/$ ha) for $D$. esculenta while that for D. alata $100 \mathrm{~kg} / \mathrm{ha} \mathrm{K}_{2} \mathrm{O}_{5}$ give the highest production (50tons/ ha). The use of bamboo stakes with the hight of $2 \mathrm{~m}$ give the best production for $D$. alata (50.69tons/ha) in comparison to that of $1.5 \mathrm{~m}$ and $1 \mathrm{~m}$ stake hights. In case of tissue culture studies, 13 cultivars of $D$. alata can be stored for eight up to 14 Months in a half strengh Murashige Skoog (MS) medium suplemented with Kinetin (Kin) and Benzil Amino Purin (BAP) of 1 to $4 \mathrm{ppm}$. Carbohydrate content of the tuber reach as high as $60 \%$ of tuber fresh weight. The diosgenin content, however, is very low, less than $1 \%$ on the average. When the corbohydrate content of the tuber is regressed against the tuber's specific grafity, a linear regression coefficient of 0.78 is obtained. Aside of the research findings, the role of yams (Dioscorea spp.) in terms of food diversification has not been improved until recently. Meanwhile, genetic erosion of yams germplasm appear to have occured rapidly among and within the species. There is, therefore, an urgency to prevent further erosion and if possible recover the lost germplasm.

\section{Introduction}

Maluku Islands, Indonesia possesses a great amount of natural resources including diversity of food crops. Sago palm, yams, cassava, coco yams, sweet potatos, bananas, as well as other food comodities are present in everydays menu of the community of the islands. However, when the richness of Maluku Province is translated into statistical data of poverty level in Indonesia in recent years, the province rank among the bottom four poorest provinces out of 34 porvinces [1]. These facts indicate that there are matters to be explained between the facts or experiences of the maluku's community and the statistical data provded by Indonesian Central Bureau of Statistics (ICBS). One dollar income per day per person (definition of poverty) used in calculating the poverty level (reduced from two dollars used in several other countries) is considered justifiable rather than using crop production or food availability which may be preferable for Maluku situation, since the definition used for all 34 provinces in Indonesia has to be the same to be validly comparing poverty level among each other, in addition to the fact that the money (dollars or rupiahs) can be readily 
converted into other human needs such as education, health recreation etc. (Ralahalu KA, former governor of Maluku Province, personal communication)

It is obvious, therefore, that the development of Maluku, has not been accomplished as expected, based on the characteristics of small islands. If better transportation facilities connecting the islands are available; if easily accessable markets are avalilable; and if the communities are well trained to improve the commodities they have, than the richness they have can be converted into currency (rupiahs or dollars) to meet the definition used, and maybe can improve the poverty level or increase the position of poverty level in statistical data given by ICBS, or may even eradicate the poverty in Maluku Province. Extensification, Intensification, Diverification and Rehabilitations have been four policies in agricultural development, conceptualized since the New Era (Orde Baru) Government of Indonesia. Improvement of the food or agricultural production especially for rice has taken place, however, mostly through extensification, that is to enlarge the cultivation area. Intensification or increasing rice production per unit area mainly done by introducing a number of superior varieties developed in neighbering countries especially from the International Rice Research Institurte (IRRI), the Philiphines and/ or by crossing certain varieties to an Indonesian variety, namely Peta [2]. Rehabilitation simply means recovering the agricultural productivity, including making use of unfertile, marginal lands for agricultural purposes. Of the four policies, diversification provides opportunity to develope and enlarge the role of various different food crops other than rice, potentially present in different parts of the country.

The development of local potential commodities, however, should be based on systematic, objective oriented and sustainable studies, so that the richness possesed can be of useful for the prosperity of the community today and for the generations to come. The need to develop local potential agricultural crops has become crucial in maintaining food security, rather than depending on outside food resources following policies implemented as a result of corona virus (Covid-19) pandemic. Studies have been conducted on yams (Dioscorea spp.), one of the potential crop commodities in Maluku islands, at the Pattimura University mainly in collaboration with United States Agency for International Development (USAID), and with a Netherlands Scientist, as well as studies in Germany by the author. These studies cover a wide area of science disipline including taxonomy, agronomy, tissue culture, genetics and plant breeding. This paper provide reports on the above studies, discuss the implication of the results and challenges faced. The report may provide a starting point for and encourage further research and development to further improve the role of yams in Maluku Islands, Indonesia.

\section{Materials and Methods}

\section{Materials}

Materials used in studies reported here include various parts (tubers, roots, leaves, flowers, fruits, seeds) of yams (Dioscorea spp.) cops/plants of different species and cultivars, Dioscorea descriptors, maschede, hoe, plow, fork, hand tractor, weight (Ohaus scale), microscope with the magnifications up to $1000 \mathrm{x}$, orcein, glacial acetic acid, absolut alcohol, destilated water, Murashige and Skoog [3] medium for in- vitro culture, hormones and vitamines, shaker, laminar flow hood, autoclave, writing materials, literatures and many others.

\section{Methods}

Materials collections were completed through collection trips to different islands in Central Maluku, South East Maluku and North Maluku Regencies (former division of Maluku Province), Maluku Provinve. Technically the collections were accoplished through gathering informations from many different sources including those of stdudents comming from different islands as well as from related government institutions, followed by collection trip to the islands and site visits togather with local partners. Samples (mainly tubers) were brought back to the project station, pictured and described, including cutting the tuber into two parts to show the tuber flesh colors. Aside of direct experiments and observations through participation in the project, some of the reports on field experiments as well as in-vitro culture works were completed throught a literature studies especially of the Final Report of the "Crop potentials of Underexploited Tuberous Plants and Aroids Project, USAID-Pattimura University [4] and the Proceedings of the Seminar, Pengembangan Potensi Tanaman Umbian (Developing the tuber crops potentials). Faculty of Agriculture Pattimura University-USAID [5]. Field experiments were mostly conducted at the experimental/collection fields/stasion at the Faculty of Agriculture, Pattimura University. The others were done at the farmers field at different places in Ambon Island as well as Seram Island.

Taxonomic studies were accomplished using 17 cultivars collected through the activities of the project. These plant materials were planted in the collection field or experimental station of the project, at the Faculty of Agriculture Pattimura University, Ambon, Maluku, Indonesia. The description was done throughout the growing season, utilizing the Dioscorea descriptors published by International Plant Genetic Resources Institute (IPGRI) with some additional characters added by the researchers. Some parts of the taxonomic studies were completed at the Institut Fuer Pflanzengenetik und Kulturpflanzenforchung (IPK), Gatersleben, Germany. Yams tubers of different accessions collected from a number of botanic gardens as well as field and market places in 
Europe and Asia and Africa were planted in green houses and the description of morphological characters were done as the plants were growing and developing.

Chromosome observation was done implementing the squash method using the fixative solution reported by Okada [6,7]. Yams tubers were culivated in the soil with high composition of sands and organic matter in plastic bags in the laboratory. The soft roots developed from the tubers were than obtained for preparat preparation leading to microscopic observations. Root tips of about $4 \mathrm{~mm}$ were disected and fixed in the fixative solution of 3 : 1 ratio of absolute alcohol and glacial acetic acid for 2 hours in room temperature. The root tips were than washed with destilated water, placed on preparat glass and further trimmed into about $2 \mathrm{~mm}$ in size. One drop of aceto orcein (2\%) staining solution was given to the root specimen, further covered with cover glass than squashed using finger tip and/or a small wooden stick. The excesive staining solution was cleaned using tissue, passed quickly through a fire flame from a bunsen burner to dry the preparat and finally observed under the microscope. Observation was done by first using $10 \mathrm{X}$ magnification of oculer lense and 10X objective lence. When cells with good mitosis division appeared, the obective lense was increased to $100 \mathrm{X}$ magnification with additon of one drop of xylol solution. The same materials (17 specimens) used in taxonomic studies at the Pattimura University, were brought to the Netherlands (by Liewe S. Anema, BSc., the Advisor of the research) to be analyzed for their diosgenin content at the University of Uthrech. The analysis of carbohydrate content of the tubers was completed at the laboratory of Soil Sciences Pattimura University, Ambon, Maluku, Indonesia. Determination of tuber's specific grafity (SG) was done at the laboratory of genetics and plant breeding Faculty of Agriculture, Pattimura University, Ambon by the following steps: tubers were first weighted normally using the scale to determine their weight (grafity) in the air (AG) than further weighted in the water to determine their weight in the water (WG). The SG was than calculated using a formula of $\mathrm{SG}=\mathrm{AG} /(\mathrm{AG}-\mathrm{WG})$.

\section{Results and Discussion}

\section{Several Facts Concerning Yams (Dioscorea spp.)}

There exist about 600 species of yams (Dioscorea spp.) in the world grouped into 60 secsions (sub-genus) according to Knuth [8], a German scientist who conducted studies on the plants/ crops morphology. Latest studies combinning morpholgical and molecular characters by the scientists at the Royal Botanic Gardens Kew, London, University of Reading, England and University of Cape Town, South Afrika, however, reported 350-400 species [9]. Yams distributed along the tropics and subtropics, small number of species distributed within the temperate region. The highest diversity of yams species, however, distributed within the wet climatic area [9]. Certain species, such as that of D. rotundata Poir and $D$. cayenensis Lamark are mainly distributed and become the major food commodities in the African continent, while D. alata L. and D. bulbifera L. are mainly distributed and become a food crops in Asia. D. trifida L. is a species mostly cultivated in the Caribbean. Yams species distributed within the temperate climatic region such as that of D. villosa L., D. balcanica Kosanin, D. caucasica Lipsky, mainly posses a rounded, woodier stem with small diameters in comparison to those distributed within the tropics, which posses slightly bigger and softer, with rounded, flat or angular-winged stems.

In addition to the underground tubers, a number of yams species including D. bulbifera, D. japonica Thumb, D. batatas Deckne, D. polystachya Turcz, D. sansibarensis (Knuth) Pax., D. macroura (Knuth) Pax. [10] D. pentaplylla L. [11] are also produce aerial tubers (bulbils). In green house cultivation at the IPK Gatersleben Germany, the aerial tubers produced by D. bulbifera (Figure 1A) can reach the size of more than that of potato; rounded and slightly flat (at the bottom) in shape, smooth skin and graysh in color. Aerial tuber produced on D. sansibarensis and D. macroura are only a few in number, smaller in size than that produced on D. bulbifera, with jolts surface, grays or dark/black skin color. $D$. polystachya produce planty of aerial tubers, small in size, jolts skin surface and grays in color. In cultivation at the yams experimental station of the "Crop Potentials of Underexploited Tuberous Yams and Aroids Projec", Faculty of Agriculture Pattimura University, Ambon, Indonesia, certain cultivars of D. alata produced one or two aerial tubers; rounded, smooth surface, grays in color and bigger in size in comparison to that of D. Polystachya (cultivated in Germany). D. pentaphylla produced many small aerial tubers with jolts surface, and grays skin color. At the experimental station in Maluku, aerial tubers were produced in the Months of June-July during a heavy rainy season and relatively cool temperature, while that in the IPK Gatersleben, Germany, they were produced in the Months of August-September.

Flowering in Dioscorea is diocious means male and female (Figure 1B,C) flowers are produced on different individual plant. Onwueme [12] reported that field cultivated yams in Tropical Africa especially D. alata and D. esculenta L., rarely produce flowers. Yams cultivation at the experimental station of the joint project, Faculty of Agriculture, Pattimura University - USAID indicated similar case as that reported by Onwueme [12] accept that D. pentaphylla (Ahei and Ahiar yams) produced flowers in the Months of June-July where the ranfall was very high and the temparture was very low at the experimental station. In green house cultivation at the IPK Gatersleben, Germany, collected species of tropical and sub-tropical origin such as D. bulbifera, D. batatas, D. japonica and D. polystachya, produced flowers in the Months of August-September, while those of temperate origin such as D. caucasica, D. villosa, D. balcanica, flowers in the Months of May - June [13]. The species produced fruits as triangle or three-winged, flat pods with seeds inside each pod (Figure 1D,E). Yams stem can be winged or rounded and can be thorny or without thorn depending on species and twining (climbing) to the right (anti clock-wise direction) or to the left 
(clock-wise direction) depending on the section (sub-genus). On Section Enanthyophyllum, where D. alata belong, the stem twins from left to right (anti clock-wise direction) opposite to that of section Combillium, where D. esculenta belong, and other sections in the Genus Dioscorea.
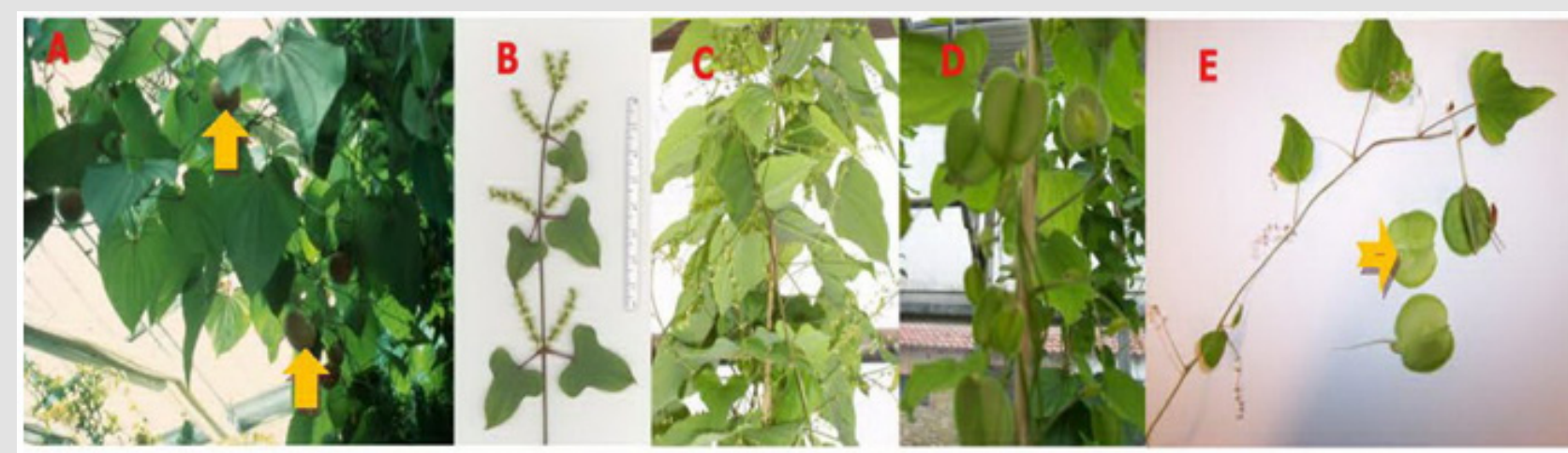

Figure 1: Some of the morphological characters of yams (Diocorea spp.). (A) Aerial tubers produced on D. bulbifera L. (arrows), (B) Female flowers produced on D. polystachya Turcz (C) Female flowers of D. caucasica Lipsky (D) Fruits of D. caucasica and (E) Fruit and seed (arrow) of D. caucasica. The plants are cultivated in pots in the green houses at the IPK Gatersleben, Germany. Pictures a and b are photographed by Dr. Joachim R. Keller of the IPK Gatersleben.

\section{Dioscorea in Maluku Islands}

In the year 1978, when the scientists of Bogor Agriculture Institute conducted a survay, in Indonesia distributed 33 species of Dioscorea, eight of them were found in Maluku Islands [14]. In the year 1989, when scientists of the joint project between Pattimura University Ambon and USAID, Crop Potentials of Underexploited Tuberous Yams and Aroids, conducted a survay, they found only four species of Dioscorea distributed in Maluku Islands: D. alata, D. esculenta, D. pentapylla, and D. hispida Dennst. Of the species D. hispida, a semi-wild and poisonous species, only one (1) land race cultivar was found, while for $D$. pentaphylla, also a semi-wild species and rarely cultivated, only two (2) land race cultivars were found. D. alata and D. esculenta were the species with the highest number of cultivars distributed in Maluku Islands. More than 50 cultivars of each of these species were collected by the joint project. Recently, however, one other species, D. bulbifera, was found in Kei islands by a researcher when collecting experimental materials for the doctorate research.

Generally, Dioscorea spp. distributed and cultivated throughout the whole Maluku Province, eventhough with different number of cultivars and intensity of cultivation from one area to the other. Of 120 tuberous cultivars/land races collected by the joint project, more than 70 of them distributed within the Central Maluku Regency, more than 40 of them distributed within the South East Maluku Regency and about 10 cultivars distributed within North Maluku Regency (based on the former Regency division). Center of cultivations of tuberous crops especially Dioscorea spp. in Central Maluku are Ambon Island (Kusu kusu, Siwang, Rutong, Hutumuri, Airlow villages), Saparua Island (Porto, Paperu villages), Haruku Island (Hulaliu village), and Seram Island (Kamarian, Tihulale, Kairatu, Waisamu Villages), in South East Maluku includes, Yamdena Island (Saumlaki, Tumbur, Lorulun, Sifnana, Wowonda,
Bomaki etc.), Wetar Island, Kei islands and in North Maluku includes Ternate Island (Figure 2).

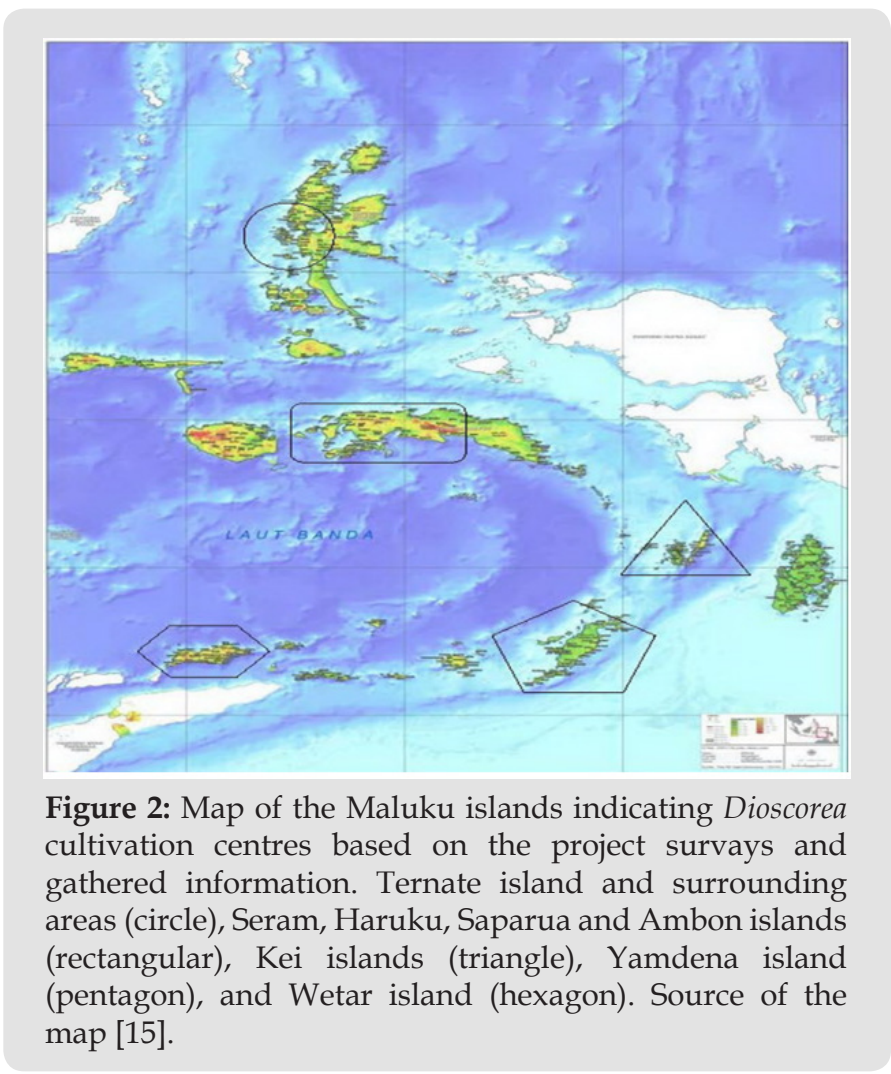

\section{Research and Development}

A significant contribution of the Faculty of Agriculture, Pattimura University in the development of tuber crops commodity especieally Dioscorea spp. in Maluku islands was realized through a joint project between Pattimura University and USAID within the year 1987 to 1990 . With supporting policies of the Rector (then Ir. 
J. L. Nanere, MSc., PhD.) and technical leadership of the Principle Investigator (Ir. J. R. Lalopua, MACE) a number of important studies have been accomplished [5,4]. In addition, several initial studies on taxonomy, genetics and breeding were also conducted in the joint work with a Netherland scientist, Lieuwe S. Anema BSc., who assisted the establishment of genetics and plant breeding laboratory at the Faculty of Agriculture Pattimura University.

\section{Field Studies}

Experiments on the methods of land preparation before soil cultivation evaluated the practices implemented by farmers in yams growing areas. Theoretically, in the growth and development of Dioscorea spp., a great amount of organic matter is needed, and the practices of burning the field after felling down the trees or burning the bushes can readily provide organic matter to be used. The experiment implemented two treatments, with and without land burning on the cultivation of ubi kelapa (D. alata.), found that the highest production at the amount of 26 tons/ha was obtained from the field burning treatment. However, this result was not significantly different, statisticly, than that without burning. Considering the additional input factors addad to the land burning practices (labours, etc.), the results suggested farmers to reconsider the practices and carefully calculating the benefit-cost ratio of yams farming system implementing the method. Dioscorea spp. utilize economic part of the crop, the tuber, as propagating materials and this practice clearly results in reduction of crop production. Experiment on seed size (seed weight) or the size of tuber part used as propagating materials, was conducted to determine the ideal seed size for high production withoud excesively reducing tuber part to be consumed. Experiment on gembili (D. esculenta) utilizing seed size of 40-50 grams, 115-125 grams, and 190-200 grams, indicated that the highest crop production was provided by the treatment of 190-200 grams seed size, followed by $115-125$ grams and 40-50 grams. With linear increase of the production as the seed size increase, there is a need for further experiments to determine the economic or ideal seed size.

Tuber part (tail, midle part or head) used as seeds as well as seed (cut tuber) placement in the soil are interresting issues to be experimented in order to determined the best practices for the best production. Studies on combillium (D. esculenta) indicated that the use of tuber's head gave the best yield, 7.69tons/ha and with the highest number of tuber in comparison to those of the middle and the tail of the tuber. Superiority of the tuber's head as seed over the middle and the tail parts of the tuber has something to do with accumulation of phytohormone, Auxin, in this tuber part, which in turn, promoting the sprouting, accelerating the formation and growth of roots and tuber. A study on seed (cut tuber) placement in the soil indicated that placement with the tuber skin faced down gave better production in comparison to that of the placement when the tuber skin faced up. This fact is explainable by the basepetal movement (through gravitation) of the Auxin, which than accumulated at the tuber skin below, promoting the growth and developmentof roots and shoots, and therefore, better production. Soil fertility is an important factor in plant growth and production including Dioscorea spp. Studies have shown that tuber production is highly responsive to Potassium fertilizer $\left(\mathrm{K}_{2} \mathrm{O}\right)$. An experiment on gembili (D. esculenta L.) indicated that the highest production of 7,72 tons/ha was achieved with the fertilization of $80 \mathrm{~kg} \mathrm{~K}_{2} \mathrm{O} / \mathrm{ha}$, while that with ubi Kelapa (D. esculenta L.), the highest production, 50 tons/ha, was given by a dose of $100 \mathrm{~kg} \mathrm{~K}_{2} \mathrm{O} / \mathrm{ha}$. Experiment on the frequency of fertilization indicated that one time fertilization with the $\mathrm{K}_{2} \mathrm{O}$ fertilizer gave better production in comparison to two and three times fertilizations.

In cultivation practices of Dioscorea, stakes have always been used to enable the twinning of the stem, facilitate better distribution of leaves to ensure better absorbtion of solar radiation, better aeration, provide good soil humudity and supress weed development. Our studies indicated that the use of bamboo stakes in the pyramide shape at 2 meter height produce the best results, 50,69 tons/ha for white yams (D. alata L.) in comparison to that of single stakes and fence stakes at the height of 1 meter and 1.5 meters. In Dioscorea farming system, multiple cropping system has always been imlemented, in which Dioscorea is planted togather with sweet potato, cassava or peas. An experiment was conducted on white yams (D. alata) grown togather with peagon pea to evaluate the advatages and disadvatages of the cropping system. The results shown that the best yield of peagon pea was obtained at the combination of two peagon pea crops with one white yam, while the best yield of white yam was obtained at monoculture system (without peagon pea). Multiple croppyng system with leguminose (peagon pea) is intended to provide Nitrogen in the soil needed for the vegetative development of yams. This study indicated, however, that the presence of legume promote competitive effects rather than supporting effects to yams.

\section{Tissue Culture Studies}

Researches at tissue culture laboratory were conducted with the short term objectives of establishing an in vitro collections of various species and cultivars of Dioscorea, and for in vitro propagations of Dioscorea spp. In the long run, the objectives can be to establishe cryopreservation collection, metabolite secunder production and/or improvement of crops genetic make up using biotechnology. In addition to other yams species, tissue culture laboratory continually collected 21 cultivars of $D$. alata. A study utilizing 13 cultivars of D. alata found that the accessions can be stored, in vitro, for eight Months in the medium with half strength Murashige and Skoog (MS), some of them can be kept for 14 Months and can be further sub-cultured. The experiment utilizing growth regulators of Kinentin (Kin) and Benzil Amino Purine (BAP) at the concentration of $1-4 \mathrm{ppm}$.

Experiments on micropropagation evaluated the influence of solid and liquid media on the growth and development of 
microplantlets of 13 Dioscore alata cultivars. The treatment of liquid medium implementing MS medium without phytohormone at the volume of $60 \mathrm{ml}$ and placed on a schaker with the speed of $90 \mathrm{rpm}$, while that of solid medium, $5 \mathrm{~g} / \mathrm{l}$ agar was added to the MS medium. Each treatment with 5 replications were placed in the cultivated room of $29^{\circ} \mathrm{C}$, with light intensity of 1600 lux from incandescent lamp. After six to eight weeks cultivation followed by observations, it was concluded that different yams cultivars responded differently to the cultivated media. As well, liquid medium, with the use of shaker, showed better shoots, roots and leaves growth and development for most of the cultivars. On the experiments of transplanting, it was concluded that there is a need for the plantlets to be cultivated in rooting medium before transplanting, to ensure further successfull growth and development.

\section{Studies at the Genetics and Plant Breeding Laboratory}

In addition to the studies at the tuberous crops project, several researches were conducted by the author for the copletion of the research thesis entitle "Taxonomy of several yams specimens, carbohydrate-diosgenin ratio and their impact on yams breeding". The studies were advised by Lieuwe S. Anema BSc, a researcher and lecturer on genetics and plant breeding at the Genetics and Plant Breeding Laboratory, Faculty of Agriculture Pattimura University, and gave following results [15]. Morphological description of 17 specimens of Dioscorea spp. utilizing Dioscorea descriptors with a number of additional characters was conducted to establih the taxonomy of the specimens and to avoid confusion due to different vernacular names given to the same cultivar, or the same name given to different cultivars in different cultivation areas. The results indicated that the 17 specimens of Dioscorea spp. fell into three different species, which are D. alata, D. esculenta, and D. pentaphylla. These results, further can be compared to descriptions of other cultivars in different regions, islands and/or villages in Maluku province to clarify the problems of different names used for one cultivar or the same name given to different cultivars. For instance, the cultivar, which in Ambon, Seram, Saparua Islands named Ubi Darah Babi (pig blood yam) or Ubi Ungu (purple yam), a cultivar with purple flesh color, might be the same cultivar as that of Arumat Dare (local name translated blood yam) of Lorulun village, Yamdena Island. This clarification is important, in part, because it enable the researchers to combine or unify the data from different institutions, in which the studies on the cultivar have been conducted.

A part of the taxonomic studues is the chromosome observation and description of the karyotype of the chromosome (number, shape and size) specifically the chromosome number. This study was not fully successful as expected. Although some good preparat showing mitotic division were obtained, chromosome counting could not possibly be done due partly to high chromosome number and small chromosome size, in addition to imperfect preparat condition. Basic cromosome number of Dioscorea reported to be $\mathrm{x}=9$ for new world yams [16] and $\mathrm{x}=10$ for old world yams [17]. Later findings indicated, however, basic chromosome number of $D$. alata to be $\mathrm{x}=20$ [18]. Most of yams species exist in high ploidi levels and sometimes causing dificulties in chromosome counting, eventhough many reports have shown successful studies. Old world species such as D. bulbifera with $2 \mathrm{n}=40,60,80$ and 100 chromosome have been reported, Similarly, $D$. esculenta with $2 \mathrm{n}=40,90,100$, and $D$. cayenensis with $2 \mathrm{n}=140$ have been counted by different researchers [12]. Martin and Ortiz [16] reported New world species such as D. floribunda Mart. and Gal. with $2 \mathrm{n}=6 \mathrm{x}=54,8 \mathrm{x}=72,16 \mathrm{x}=144, D$. mexicana Guillemin with $2 \mathrm{n}=4 \mathrm{x}=36$, and $D$. composita Hemsl with $2 n=6 x=54$. Other than poliploidy chromosome number, preparat preparation techniques still need to be improved in this study. Understanding karyotype of the cromosome is not only important for taxonomical purposes but also breeding purposes.

Carbohydrate contents of the 17 specimens of the experimental materials as well as some of the tuberous crops of project's collection, analyzed at the soil laboratory, Faculty of Agriculture Pattimura University, indicated high percentages, up to $60 \%$ of tuber fresh weight, when samples were the mixed of whole tuber, and up to $70 \%-80 \%$ for the head of tuber when samples were analyzed separatedly for head, middle and tail of the tuber. A regression equation was established between tuber specific grafity and coabohydrate contents utilizing the 17 Dioscorea specimens. The linier regression coeficient of $\mathrm{R}=0.78$ is considered quite high for practical uses, that is to estimate carbohydrate content of the tuber without laboratorium analysis (only by weighing the tuber). A note on this regression is that the tuber flesh should be white in color, or other color of tuber flesh (purple, in this case) will reduce the value of regression coefficient. Purple color of the tuber flesh is assumed to contain more of other compound than carbohydrate (anthocyanin, for example). This experiment, surely still have to be repeated several times, utilizing higher number of samples to be able to increase its precision and reliability. However, the benefits of using the regression are reduction of the cost of analysis, or when the study is conducted in a remote area and carbohydtae content need to be determined, roughly. Results of the diosgenin analysis on 17yams specimens at the Utrech University the Netherlands indicated very low percentages (below 1\%), mostly zero, diosgenin content. Diosgenin, $\mathrm{C}_{27} \mathrm{H}_{42} \mathrm{O}_{3}$, a steroid chemical compound has been used widely in pharmaceutical industry especially for treating cancers [19] and as an active ingradiend in contaceptive pill [20]. Some of the new world yams found to contain high percentage of diosgenin and have been cultivated for the purposes of extracting the diosgenin compound including D. composita (contain 4-6\%), D. floribunda (contain 6-8\%) and D. spiculiflora Hemsl. (contain 8-14\%) [21].

Based on the results of the analysis of carbohydrate and diosgenin contents of the tuber, it is concluded that development of yams species and cultivars in Maluku islands should be directed to their use as cabohydrate source or as food crops and not as 
diosgenin source crops, and breeding efforts can be directed partly to improve their carbohydrate contents. It is assumed that in a very long process, community of the Maluku islands, maybe unconciously, have selected the present cultivars for the purpose of consuming their carbohydrate or as food crops from generation to generation. This assumption is justifiable since diosgenin has a bitter taste and present in wild species/varieties and therefore, the commuinty did not consume species/varieties/genotypes with high diosgenin content, but cultivate and consume varieties which has no bitter taste and in the process, selected for genotypes with high carbohydrate content.

\section{Implementation of the Experimental Results and Further Development}

Achievements of the joint project, "crop potetntial of underexploited tuberous: yams and aroids" can be evaluated through the accomplishments shown during three years project's contract including; survays, collections, cultivar descriptions, estimation of number of species and cultivars in Maluku islands, mapping/ determination of yams distribution or cultivation centres/areas, field and in vitro conservation and multiplications/propagations, analyses of important chemical contents, agronomic experiments (method of land preparations, preparation and placement of seeds on the soil, fertilizers and fertilization, staking etc.), joint field work/ cultivation with the farmers in Hulung village, Ambon Municipality, banefit-cost analysis of yams farming system, organoleptic tests of various yams products, etc. ended with a national seminar entitled "development of tuberous crops potentials" in order to desseminate the acchievements to scientists, practicians, policy makers etc., as well as project reports including four-monthly reports and final reports comprising pictures report and written report, and proceedings of a seminar which are presented to the sponsor (USAID) as well as a number of stake horder institutions in Maluku Province. Despite all the acchievements, there has not been any notable development on tuberous crops commodities including yams, seen in about 30 years time following the termination of "Crop Potential of Underexploited Tuberous; Yams and Aroids" project.

In vitro culture studies, either seed propagation/multiplications, in vitro collections and conservations, as well as studies concerning nutritional and chemical values, taxonomy, genetics and breeding can be as the base for further studies or for practical uses when it is possible. A part of the possible ways of development is the selection for cultivars with high carbohydrate content, attractive tuber flesh color, tuber shape and size preferable by busniss sector (including for selling in super merkets) and consumen, taste and other preferable characters which are than inventorate and recomended to farmers and other attracted parties. Results of the field experiments, which have studied the problems at farmers level need to be given back to farmers through extention services and field demonstrations in order to strenghten and improve farming practices as well as to change or to avoid farming practices which are not beneficial including, for example, shifting cultivation by cuting down the forest and burning the field in order to readily provide organic matters for yams growth and development. Applications of better farming practices could than improve land productivity or be more benefitial to farmers and therefore motivate and enlarge yams farming system. Food products of yams in Maluku islands are mainly remain traditional, home made, from boiled yams, stone burned yams, smoked yams, yam puree, fried yam, yam chips and yams getuk cake and a number of other food products. Improvement to commercial level or home industry has not been clearly seen. In different parts of Indonesia, various improved products of yams have been produced and their recipes can be obtained from a number of internet sites. The products of purple yams (ubi ungu), for examples, can be as wet-cake purple yam, brownies purple yam, pudding purple yam, lemper purple yam, cup cake purple yam, bolu cake purple yam, talam cake purple yam, chiffon cake purple yam, donut purple yam, role dadar purple yam, klepon cake purple yam, and etc. Indeed, a product of rice purple yam, has been presented in national exhibitions, as a part of the effors to facilitate transition from rice consumtion to yams consumtion supporting the policy of diversification.

One of the main reasons for slow rates of yams exploitation and product improvement in Maluku Province and in Indonesia in general is the lack of supportive government policy. An example for the above statement is that the species Dioscorea alata was not listed as one of the food commodity, among 36 food commodities, in Indonesia (rice, 5 species of palawija, and 30 species of leguminose and tuberous crops) in the Decision Letter of the Agriculture Minister of the Republik of Indonesia, number 511/Kpts/PD. 310/9/2006 dated 12 September 2006 [22]. As a consequence, D. alata received no attantion in the discussion concerning vision, mission, and development strategy as well as fundings allocation for its development in the stategic plan of the Directorate General of Food Crops in the year 2010-2014. Dioscorea alata, therefore, despite its high potential in answering the food diversification policy in a number of provinces, has always been developed through self initiative and efforts of the local commuinities. Learnig from the experience of other countries regarding Dioscorea development; countries in Africa produce about $95 \%$ of 37 million tons of the world production in 1999 [23]. Domestic uses in Africa reach 15,8 million tons [24] with the possibility of development as fresh tuber for human consumtion, processing for animal feed, processing as flour for bread making, especielly for D. alata [25]. As part of the roots and tuber crops, development vision for Dioscorea in the year 2020 are to contribute to the world food system through its integration into emerging markets through eficient and environmentally friendly products as well as high quality, competitive products as sources of food, feed, and industry [25]. 


\section{Germplasm Erosion and Solution Alternatives}

In recent years, it is seldom to run into Dioscorea spp. in traditional markets, even more in super markets in Ambon city. When present, mainly of cultivars coconut yam (ubi Kelapa-Figure 3E) and white yam (ubi Putih-Figure 3D) of D. alata, and one or two cultivars of $D$. esculenta (Figure 3A,B). In fact, it has been the case for quite a long time since only a few cultivars of certain species are preferable by the consumers, the others are cultivated only for family consumption or for other purposes. For example; snake yam (ubi Ular) of D. alata with a long, rounded and waify or coiled tuber is cultivated at the border of the farmers field or gardens and twining its stem on the fence or function as the fence. The scarcity of yams commodity found in the market, can also be an indication of yams genetic erosion, aside from the survays data indicated previously. Economic preasure might also have caused the farmers to abandone cultivars, chich are not well sold in the marked, utilizing the lands they have, efficiently, to cultivate the species and cultivars attracted to the consumers only.

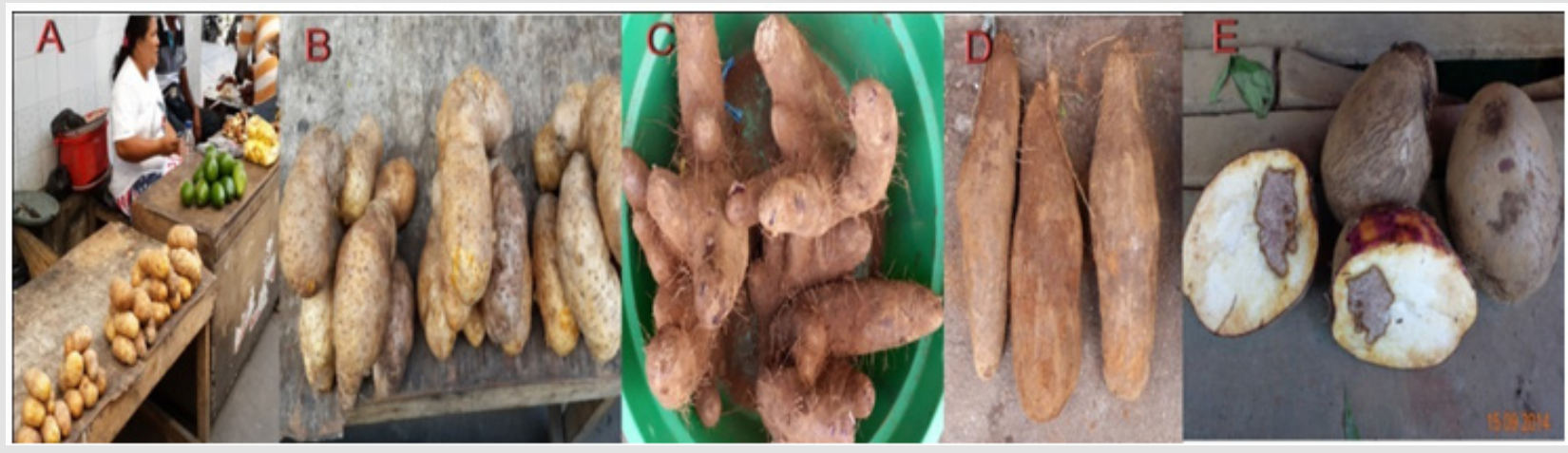

Figure 1: It is not often to find Dioscorea spp. in the market place in recent years, in Ambon island (Capital of the Maluku province). The pictures show one cultivar of D. esculenta (A and B) and three cultivars of D. alata, which could be fan yam (ubi kipas-C), white yam (ubi putih-D) and coconut yam (ubi kelapa-E), encountered at different times of market visitations.

The lost of yams germplasm, not only means the scarcity of food crops, which may support diversification in food and nutrition as well as maintaining food security, but also means narrowness of crops genetic diversity, from which, selections and coss-breedings can be made to obtain superior varieties in the future. A hope for the conservation of yams' genetic resources is present on the inter-situ conservation method through seasonal cultivation by the farmers or on-farm management. This method is supported by the traditional culture or indigenous practices, which assigned a certain family to cultivate or manage a certain cultivar or the tradition, which identify a certain family with certain yams cultivar. Another cultural practice is having a competition, periodically, on variety of food products prepared from various yams cultivars. This hope, however, is getting faded away as the local wisdoms or traditional cultural practices of germplasm conservation are dissapearing [26].

The joint project of USAID-Pattimura University, which collected more than 120 accessions, mostly Dioscorea spp., both field and in vitro cultures is obviously not only a research project but also an effort to conserve yams germplasm. The mehods and techniques used are considered to be effective and economics since they are the only methods available for the ex-situ conservation of recalcitrant and semi-recalcitrant seeds, as well as vegetatively propagated crops. The in-vitro conservation may than followed by protocol development for cryopreservation, that is a technique/ method of preserving biological materials in liquid nitrogen for an unlimited time period. These three methods or techniques of ex-situ germplasm conservation mainly implemented in the world today, each with its advantages and disadvantages, will complement each other, in which, cryopreservation will be a long-term germplasm preservation as well as a back-up or duplicate of field and in-vitro collections. Field collection and in-vitro collection, beside being back-up for each other, aslo are short-term collections or working collections for germplasm exchange and for scientific research and development, and further utilization of the conserved germplasm.

Unfortunately, the project was ended with the ending of the time period of memorandum of understanding $(\mathrm{MoU})$ between the two parties (USAID and Pattimura University). Togather with the termination of the project, are the efforts of collection and conservation as well as intensive research and development of yams germplasm in Maluku islands. Experimental station with facilities, administration building and offices, library and literatures possesed could not be continuously preserved and utilized. Germplasm collections possesed have to be left erroded, wasting all the survays and collection trips, research and development works and the fundings alocated. What left are information gathered and reports written about project activities including the number of cultivars and their distribution areas in Maluku islands and, hopefully, the cultivars can still be found at their cultivation areas when furthur research and development are to be conducted in the future. There is a need for government and community efforts to conserved the presently existing yams germplasm and when possible recovering the cultivars and land races, which considered extinct or rarely found. The efforts can be done through an establishment of a gene bank or in the small scale at the community level, a community 
gene bank. Examples of the recovery of the extinct germplasm at their original area of distribution and cultivation, include the recovery of plant genetic resources collection of the country, Albani, destroyed during the war of 1990's, by the gene bank of the Institut fuer Pflanzengenetik und Kulturpflanzenforchung (IPK) Getersleben, Germany, with the same plants genetic resources collected in Albany by German scientists during the second world war [27]. This act of germplasm recovery was surely accompanied by a document of material transfer agreement (MTA).

\section{Conclusion}

Yams (Dioscorea spp.) has a great potential of genetic diversity in Maluku Islands. About a hundret cultivars, mainly of D. alata and $D$. esculenta have been identified, cultivated in a number of cultivation centres including Seram, Ambon, Saparua, Haruku, Yamdena, Wetar and Ternate Islands of Maluku Province. These species and cultivars have been a part of the diversity of food commodities in Maluku islands and contributing to diversification policy in food and nutrition of indonesian government. Studies conducted at the Faculty of Agriculture, Pattimura University either through a joint project with the USAID or through a research supervision of a Netherland scientist have revieled a number of findings. Field experiments have shown, in part, that the shifting cultivation, which maily practiced in Yamdena island, may not be highly beneficial for the farmers and should be reconsidered in its practices or be avoided. In vitro studies have indicated, in part, that yams cultivars can be kept or conserved up to 14 Months without loosing the ability to be further propagated. Results of taxonomic studies have the potential of avoiding confusion in the name given to certain cultivars due to the similarity in the name but dissimilarity in morphological characters or the other way around. Analysis of carbohydrate and diosgenin contents revealed that the development or breeding program of Dioscorea in Maluku islands should be directed or objected to development of Dioscorea as carbohyrate source crops and not as diosgenin source crops.

These research findings, however, have not been well implemented for further development of Dioscorea due partly to the lack of funding after the termination of the project, and lack of supporting policy. At the same time, there is an occurance of germplasm erosion indicated either through survays data as well as the scarcity of the crops commodity in the market places. Conservation efforts through on-farm management supported by local wisdoms and practices seems to be slowing down due to the continuing dissappearance of the local wisdoms and practices. There have to be a concerted efforts of government and community in the conservation of yams germplasm, so that yams (Dioscorea spp.) can be continuosly play an even bigger role in the diversification policy in Maluku islands. A gene bank or/and a community gene bank are proposed to contribute to yams germplasm conservation.

\section{Acknowledgements}

The studies were partially supported by different sources of funding, namely USAID, A Netherlands Funding Agency, DAAD, IPK Gatersleben, Germany and Indonesian Government. The manuscript was read by Prof. Mike Evans of the University of British Columbia, Canada and provided his opinion. The author thanks Mr. Luud Clercx of Agrofair Company, Rotterdam the Manager of Blended Learning Value Chain (BLVC), Indonesia-Netherlands joint project for supporting the publication.

\section{References}

1. (2020) Badan Pusat Statistik (BPS) Persentase Penduduk Miskin Menurut Provinsi 2007-2020.

2. (2014) Pustaka Sekolah. Revolusi hijau.

3. Murashige T, Skoog F (1962) A revised medium for growth and bioassays with tobacco tissue culture. Physiol. Plant 15: 473-497.

4. Lalopua JR, Wattimena RE, Walsen A, Raharjo SHT, Leunufna S, et al. (1990) Final Report. Crop potential of underexploited tuberous yams and aroids project. Faculty of Agriculture Pattimura University, AmbonUnited States Agency for International Development (USAID). Ambon.

5. Lalopua JR, Wattimena RE, Walsen A, Raharjo SHT (1989) Penelitian tanaman umbian pada Fakultas Pertanian Universitas Pattimura. In: Pattimura University and United States Agency for International Development (USAID) (Eds.), Proceedings Seminar, Pengembangan potensi tanaman umbian. Ambon pp. 95-134.

6. Okada H (1984) Chromosome counts of some plants collected from sumatra. In: Hotta M (Eds.), Forest ecology and flora of G Gadut, West Sumatra. Sumatra Nature Study (Botany), Kyoto pp. 89-90.

7. Okada H (1986) Cytotaxonomical observation of some plants collected from West Sumatra. In: Haota M (Eds.), Diversity and dinamics of plant life in Sumatra. Sumatra Nature Study (Botany), Kyoto pp. 61-70.

8. Knuth R (1924) Dioscoreaceae. In: Engler HGA (Eds.), Das Pflanzenreich, 87 (IV). Verlag von Engelmann W, Leipzig.

9. Caddick LR, Wilkin P, Rudall PJ, Hedderson TAJ, Chase MW (2002) Yams Reclasified: a reclasification of Dioscoreaceae and Dioscoreales. Taxon 51(1): 103-114

10. Leunufna S, Keller JR (2004a) Determination of Dioscorea experimental materials of tropical and sub-tropical origin. Institut fuer Pflanzengenetik und Kulturpflanzenforschung (IPK) Gatersleben, Germany.

11. Leunufna S (1987) Taxonomi beberapa spesimen Dioscorea, ratio karbohidrat-diosgenin dan dampaknya terhadap prosedur pemuliaan. Thesis. Faculty of Agriculture, Pattimura University, Ambon.

12. Onwueme IC (1978) The tropical tuber crops: Yams, Cassava, sweet Potato, Cocoyams. Willey and Sons, Chichester and New York, USA.

13. Leunufna S, Keller JR (2004b) Description and identification of some temperate (wild/undultivated) species of Dioscorea. Institut fuer Pflanzengenetik und Kulturpflanzenforschung (IPK) Gatersleben, Germany).

14. Guharja E, Sudiarto A, Wiroreno ON (1978) Dioscorea di Indonesia. Institut Pertanian Bogor (IPB) Bogor.

15. (2009) Posko Badan Nasional Penanggulangan Bencana (BNPB), Peta kepulauan Maluku. geospasial.bnpb.go.id. Badan Nasional Penaggulangan Bencana (BNPB).

16. Martin FW, Ortiz S (1966) New chromosome numbers in some Dioscored species. Cytologia 31(1): 105-107. 
17. Martin FW, Ortiz S (1963) Chromosome numbers and behavior in some species of Dioscorea. Cytologia 28(1): 69-101.

18. Arnau G, Nemorin A, Maledon E, Abraham K (2009) Revision of ploidi status of Dioscorea alata L. (Dioscoreaceae) by genetic and microsatellite segregation analysis. Theoterical and Applied Genetics J. 118(7): 12391249 .

19. Raju J Metha R (2009) Cancer chemopreventive and therapeutic effects of diosgenin, a food saponin. Nutr Cancer 61(1): 27-35.

20. Anonymous (2010) Chemestry World. The Contraceptive pill, the birth of the pill.

21. Martin WF, Gaskin MH (1968) Cultivation of sapogenin bearing Dioscorea species. Prod Res Rep, (103), USDA, Washington DC.

22. (2012) Direktorat Jendral Tanaman Pangan-Kementan Rencana Strateg Direktorat Jendral Tanaman Pangan Tahun 2010-2014.

ISSN: 2574-1241

DOI: 10.26717/BJSTR.2020.29.004764

Semuel Leunufna. Biomed J Sci \& Tech Res

(C) This work is licensed under Creative

Submission Link: https://biomedres.us/submit-manuscript.php
23. (2001) Food and Agricultural Organization (FAO). Production Yearbook, $53,1999$. Rome.

24. (1999) Food and Agricultural Organization (FAO). FAOSTAT statistics database (online). Various Months, http://apps.fao.org.

25. Scott GJ, Best R, Rosegrant M, Bokanga M (2000) Roots and tubers in the global food system, a vision statement to the year 2020. International Potato Centre, Lima

26. Leunufna S, Evans M (2014) Ensuring food security in the small islands of Maluku: a community genebank approach. Journal of Marine and Island Cultures 3:125-133.

27. Knupfer H (2010) The Balkan collections 1941-1942 of Hans Stubbe in the Gatersleben Gene Bank. Czech J. Genet. Plant Breed 46: 527-533.

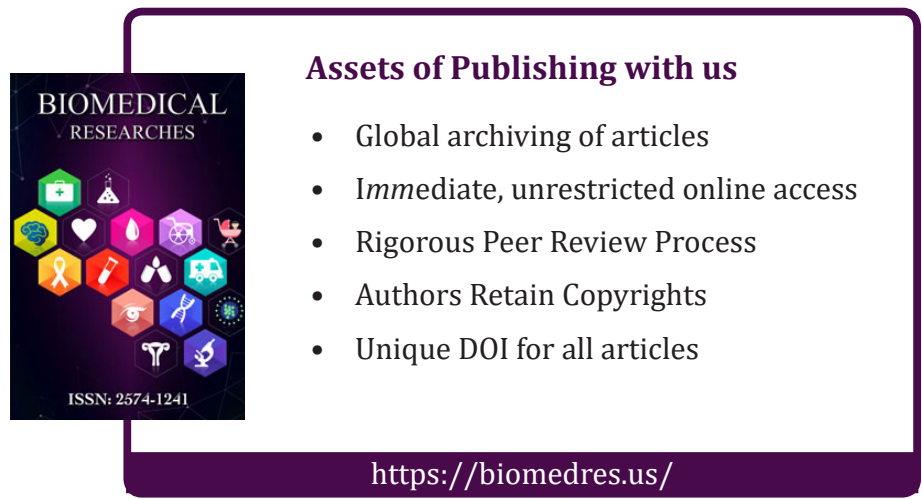

